\title{
"Book Review: FRANKFURT, Harry G. On Inequality. Princeton and Oxford: Princeton University Press, 2015, 102 pp., \$14.95 (hbk), ISBN $9780691167145 . " 1$
}

\author{
Andrea Luisa Bucchile Faggion \\ Universidade Estadual de Londrina - Filosofia \\ Rodovia Celso Garcia Cid | Pr 445 Km 380 | Campus Universitário Cx. Postal 10.011 | \\ CEP 86.057-970 | Londrina - PR, Londrina 86057-970 \\ Brazil \\ andreafaggion@gmail.com
}

Article info

CDD: 501

Received: 10.10.2016; Revised: 00.00.0000; Accepted: 22.10.2016

DOI: http://dx.doi.org/10.1590/0100-6045.2016.V39N3.AF

Keywords:

Inequality

\begin{abstract}
On Inequality is a short book that skillfully handles a challenging topic. As its title suggests, its focus is a major theme in contemporary theories of justice: equality. Contrary to what one might expect, however, Frankfurt's critique of equality is not grounded in libertarian arguments or an ideal of the minimal state. Rather, it aims to clarify a cluster of alleged conceptual confusions about equality as a constitutive moral value.
\end{abstract}

Frankfurt begins by making a familiar point against the imposition of strict economic equality: "Inequality of incomes might be decisively eliminated [...] just by arranging that all incomes be equally below the poverty line" (p. 3). We should not infer from this, however, that Frankfurt reduces egalitarianism to economic egalitarianism, a trend of thought that argues for a brand of equality according to which everybody enjoys the same wealth.

\footnotetext{
${ }^{1}$ Except where otherwise indicated, all references are to this text and are noted parenthetically.
}

Manuscrito - Rev. Int. Fil. Campinas, v. 39, n. 3, pp. 245 - 251, jul.-set. 2016. 
Moreover, Frankfurt's refusal to grant moral relevance to equality as such does not entail that he does not regard poverty as a moral problem. This is why he replaces egalitarianism with a doctrine of sufficiency - "the doctrine that what is morally important with regard to money is that everyone should have enough" (p. 7) - which also proscribes "economic gluttony" (p. 3). According to Frankfurt, egalitarianism misconstrues the real challenge of reducing "poverty and excessive affluence" (p. 4). Indeed, Frankfurt suggests that most people agree with him on this; what we really find repugnant when we express disapproval of inequality is another feature of the situation: the fact that some people have too little (p. 40).

However we determine the concept of sufficiency, it is not a comparative concept. In other words, according to Frankfurt, the amount of money available to others is not directly relevant to determining what is needed for a certain kind of life (p. 10). Thus, instead of focusing on alleged conflicts between the pursuit of equality and freedom, Frankfurt emphasizes what he considers a form of moral disorientation caused by the pursuit of equality. The pursuit of equality as a good in itself distracts us from what is truly significant (p. 13).

Frankfurt is willing to admit that the concept of having enough is hardly precise: " [] $\mathrm{t}$ is far from self-evident precisely what the doctrine of sufficiency means, and what applying it entails" (p. 15). When he returns to the question "What does it mean for a person to have enough?" he notes that the assertion that a person has enough entails only that a requirement has been met, not that a limit has been reached. In other words, it's not bad to have more than enough (p. 47).

Certainly, the main problem is how to specify the content of such a requirement, especially if one keeps in mind that this content entails claims of justice to be addressed by public policies. What counts in this specification? Is it the attitudes people actually have about the issue, or the attitudes it would be reasonable for them to have (p. 99, n. 15)? If the latter, what criterion of reasonableness would be useful here?

Frankfurt rejects the possibility that sufficiency is related to having enough to avoid misery (p. 49), which would be the only easy way to determine a pattern of sufficiency. The above questions are thus as difficult as they are important. They are also questions, however, that go beyond the limits of Frankfurt's essay. In this work, Frankfurt merely warns against 
hastily adopting an inadequate alternative in the face of the difficulties associated with the doctrine of sufficiency (p. 15).

Frankfurt emphasizes that his interest is analytical rather than political (p. 65). In the end, however, it will seem obvious to some that Frankfurt's doctrine of sufficiency risks ultimately being much less economically feasible than egalitarianism if developed as a theory of justice - even if Frankfurt is right about the fact that this does not count as a reason to adopt egalitarianism. Indeed, this does not even count against the claim that what lurks behind our disapproval of inequality is really the ideal of sufficiency.

With this noted, what really matters here is whether Frankfurt is right about its being unreasonable for someone to be unsatisfied about her life only because her standard of living is bellow that of others (p. 73). In other words, is equality an important component of sufficiency itself? Would it be unreasonable to be unsatisfied with your life if everyone else were at least ten times wealthier than you? Some will understandably doubt Frankfurt's take on this issue.

Still on the topic of economic equality, Frankfurt considers arguments based on marginal utility, according to which economic equality would maximize the aggregate satisfaction of members of society. The idea is that the marginal utility of money necessarily diminishes for the wealthy, and thus that the redistribution of income and wealth provides money to those for whom it has more marginal utility. An argument along these lines is presented by Abba Lerner, who is quoted by Frankfurt as follows:

The principle of diminishing marginal utility of income can be derived from the assumption that consumers spend their income in the way that maximizes the satisfaction they can derive from the good obtained. With a given income, all the things bought give a greater satisfaction for the money spent on them than any of the other things that could have been bought in their place but were not bought for this very reason. From this it follows that if income were greater the additional things that would be bought with the increment of income would be things that are rejected when income is smaller because they give less satisfaction; and if income were greater still, even less satisfactory things could be bought. The greater the income, the less satisfactory are the additional things that can be bought with equal increases of income. That is all that is meant by the principle of the diminishing marginal utility of income. (qtd. on p. 28)

Manuscrito - Rev. Int. Fil. Campinas, v. 39, n. 3, pp. 245 - 251, jul.-set. 2016. 
Frankfurt's first reply to this kind of argument is grounded in his concept of a "threshold effect". The satisfaction obtained via the purchase of the last item in a series may be greater than the satisfaction obtained by purchasing the other items because the last item represents the crossing of a threshold. The experience of collectors illustrates this point. Frankfurt's second reply involves the refusal to accept Lerner's assumption that if a consumer refrains from obtaining a certain good until his income increases, this necessarily means that he rejects it when his income is lower (p. 32). According to Frankfurt, even where a consumer does not save money to purchase a certain good, this doesn't necessarily mean that he rejects that good and prefers the good he actually purchases. The consumer may regard saving for a particular purchase as pointless because he believes that he will not be able to save enough money within an acceptable period of time ( $\mathrm{p}$. 97 , n. 10).

Thus Frankfurt claims that it is not the case that economic egalitarianism maximizes aggregate utility in society. Indeed, Frankfurt believes that an egalitarian distribution may minimize aggregate utility in certain circumstances: "[W] hen resources are scarce, so that it is impossible for everyone to have enough, an egalitarian distribution may lead to disaster" (p. 36). Frankfurt's example is a situation in which there is enough medicine and food to enable some members of a population to survive but where an equal distribution of these resources would result in nobody's receiving enough, and thus in everybody's death (p. 34). This line of thought is reminiscent of theories of justice according to which justice is meaningless in contexts of extreme scarcity and abundance (see, for instance, Hume, 2006, p. 93-94). Frankfurt is thus open to the objection that it is not only egalitarianism but indeed any conception of justice that would be inapplicable in such circumstances.

With the above noted, the ideal of equal respect and concern is much more relevant to contemporary theories of justice than strict economic equality. The most important part of Frankfurt's book is therefore his analytical attempt to illustrate what he takes to be a conceptual confusion at the root of this ideal:

Enjoying the rights that it is appropriate for a person to enjoy, and being treated with appropriate consideration and concern, have

Manuscrito - Rev. Int. Fil. Campinas, v. 39, n. 3, pp. 245 - 251, jul.-set. 2016. 
nothing essentially to do with the consideration and concern that other people are shown or with the respect or rights that other people happen to enjoy. Every person should be accorded the rights, the respect, the consideration, and the concern to which he is entitled by virtue of what he is and what he has done. The extent of his entitlement to them does not depend on whether or not other people are entitled to them as well. (p. 75)

Frankfurt's point - perhaps echoing Aristotle - is that philosophers like Dworkin (see, for instance, 1985 and 2011) have mistaken the moral requirement to be impartial or avoid arbitrariness for the moral requirement to treat people with equal respect and concern: "To avoid arbitrariness, we must treat likes alike and unlikes differently. This is no more an egalitarian principle than it is an inegalitarian one" (p. 101, n. 3).

Importantly, Frankfurt is not denying that there are rights that belong to every human being by virtue of their humanity. Where this is the case, however, your having the right in question is not grounded in a principle of equal treatment. Your right is explained by your having a characteristic that others also have. In other words, impartiality requires us to treat equals as equals, but it doesn't require of us that we view everybody as equal.

According to standard contemporary conceptions of justice, equality is not to be embraced no matter what the circumstances. On the standard egalitarian view, equality is more like an original position, for which justifications are unnecessary and from which divergences must be justified. Nonetheless, if Frankfurt is right, equality is not this species of moral position by default, or a constitutive moral principle. It is necessary to argue for the requirement of equal treatment (by showing that there are no relevant differences between two persons, for instance) (p. 77-78).

To sustain his thesis, Frankfurt challenges a scenario made famous by Berlin. It's worth reproducing the passage quoted by Frankfurt in full:

The assumption is that equality needs no reason, only inequality does so... If I have a cake and there are ten persons among whom I wish to divide it, then if I give exactly one tenth to each, this will not, at any rate automatically, call for justification; whereas if I depart from this principle of equal division I am expected to produce a special reason. (qtd. on p. 80)

Manuscrito - Rev. Int. Fil. Campinas, v. 39, n. 3, pp. 245 - 251, jul.-set. 2016. 
Frankfurt claims that it is not the moral priority of equality that explains why we should divide Berlin's cake into equal shares. In Frankfurt's view, the key feature of the situation is the lack of relevant information. If a distributor has no information at all about those among whom she is to distribute something, this amounts to a situation in which each person is identical to the others. This is why the cake should be divided into equal shares:

It is the moral importance of respect, and hence of impartiality, rather than of any supposedly prior or preemptive moral importance of equality, that constrains us to treat people the same when we know nothing that provides us with a special reason for treating them differently. (p. 81)

It is true that Frankfurt's point here looks like a dispute about words, since both Frankfurt and the egalitarian agree that Berlin's cake should ultimately be divided into equal shares. Yet the implications of Frankfurt's point are highly relevant. If equality on its own cannot justify, say, a rights claim, then the discussion is really about entitlement. The concept of entitlement is generally neglected in contemporary philosophical debates about social justice. It's as if the resources discussed in these debates appeared from nowhere, such that the only relevant issue is whether there is justification for departing from a policy of equal distribution - such as differences between conceptions of the good, as in Dworkin (1985), or the fact that the "cake" diminishes when divided into equal shares, as in Rawls (1999). Against this background, Frankfurt's essay is a breath of fresh air for contemporary philosophy.

\section{References}

DWORKIN, Ronald. A Matter of Principle. Cambridge, Massachusetts; London, England: Harvard University Press, 1985. Justice for Hedgehogs. Cambridge, Massachusetts; London, England: Harvard University Press, 2011.

Manuscrito - Rev. Int. Fil. Campinas, v. 39, n. 3, pp. 245 - 251, jul.-set. 2016. 
HUME, DAvid. Moral Philosophy. Ed. Geoffrey Sayre-McCord. Indianapolis/Cambridge: Hackett Publishing Company, 2006.

RAWLS, JOHN. A Theory of Justice: Revised edition. Cambridge, Massachusetts: Harvard University Press, 1999. 